\title{
Exploring Organizational Trust as Mediator in the Relationship between HRM \\ Practices and Organizational Performance
}

\author{
* Ahmad Ali \\ ** Prof. Dr. Muhammad Zahid Awan \\ *** Dr. Aziz Javed
}

\begin{abstract}
The management of human resources is indispensable for each organization, whether public or private including higher educational institutions. Concerning the management of human resources, there are certain globally recognized practices those which are considered as the building blocks for organizational performance and success. Along with this, some other factors are also considered as crucial elements in the success of these organizations. Among these factors, organizational trust is considered as the most critical due to its vital role in reshaping the confidence of the individuals in organizations. The trust of employees has been identified as a critical factor in defining the overall organizational behavior of the workforce. For this purpose, some hypotheses have been developed from the theoretical framework about the relationships between HRM practices (predictors) organizational performance (criterion) and the organizational trust (mediator) which were tested over the statistical tools like correlation, regression, and mediation. This study aimed to explore above-said relationships by taking higher educational institutions under consideration with teachers as respondents in the southern region of Khyber Pakhtunkhwa, Pakistan by providing some valuable recommendations to the higher education management and the future researchers.
\end{abstract}

Keywords: $\quad$ HRM Practices, Organizational Trust, Organizational Performance \& HEIs

Introduction

In the contemporary era, where globalization is taking place in every sphere of life, the management of human resources becomes vital for organizations. However, higher education institutions play a crucial role in today's knowledge-based economy (Paauwe \& Boselie, 2003). The fact is that the HEI's are not only the grooming fields for its human resources rather it provides professional expertise in the shape of proficient employees to the various sectors of the country as a whole (Gordon \& Whitchurch, 2007). Human resource management (HRM) with certain allied practices is vital for the successful performance of any higher educational institution. Similarly, organizational performance depends upon several measures which the academicians considered as the significant factors for the performance of the organization (Kumar \& Gulati, 2010). Thus, HRM practices are considered as the successful building blocks for the performance of the organization (Popescu \& Băltăreţu, 2012). In a similar layer, there are certain intermediary factors exist that may affect the links of organizational performance with Human Resource Practices, among which the organizational trust has been considered the critical factor in affecting the relationship between HRM practices and $\mathrm{OP}$.

Organizational performance is a prerequisite for the sustainable development of the organization in today's tough competitive circumstances. It is only the decent performances, which bring about the status/rank of organizations at par with global standards (Arshad, Azhar \& Khawaja, 2014). The previous studies reveal that many attributes count for the organizational performances among which some are considered as most important due to their overwhelming role towards organizational credibility (Malam, Tang \& Raihan, 2016). All these attributes of organizational performance are the most crucial elements for organizational success. The literature revealed that the

\footnotetext{
* Institute of Business Administration, Gomal University, Dera Ismail Khan, KP, Pakistan

** Institute of Business Administration, Gomal University, Dera Ismail Khan, KP, Pakistan

*** Institute of Business Administration, Gomal University, Dera Ismail Khan, KP, Pakistan
} 
effective management of human resources plays a vital role in organizational performance. There are certain practices involved in human resource management which are termed as the HRM practices (Awais, Afzal, Shahzadi \& Khalid, 2017). These practices are considered by researchers are the most effective gears towards organizational performance (Haq, Ilyas \& Mahmood, 2018). These practices are countless; however, the most vital are recruitment $\&$ selection and training $\&$ development. These practices are accepted by researchers to have a greater and eminent relationship and ultimate impact upon organizational performance.

\section{Literature Review \\ HRM Practices}

During the past decades, it was widely recognized that effective implementation of human resource management is the key to the sustainable development of the organizations (Colakoglu, Lepak \& Hong, 2006). In this regard, in the contemporary competitive era, for organizational performance, HRM practices are the only prerequisite behind the success and development of each organization (Wang \& Shyu, 2008). The same is the case in higher educational institutions context being the highest seat of teaching and learning. There are many practices available in previous researches, however, the amalgam of these practices is recruitment \& selection and training \& development (Kumar \& Gulati, 2010). The literature revealed that all these practices are vital gears towards organizational success (Ali, Saeed, Soomro \& Aslam, 2015). In the same line, this study adds the most critical phenomenon in the association between HRM practices and organizational performance, which is an organizational trust used as a mediator (Lazim \& Perlis, 2016). This section provides an overview of the definition and importance of research concepts/variables under consideration.

\section{Recruitment and Selection}

The human resource management practices initiated from recruitment and selection. Researchers defined this concept, a selection of suitable candidates (capable \& competent) for employment in the organization by comparing the job demands/requirements and prerequisite skills, knowledge, and competencies through a transparent process of recruitment and selection (Katou \& Budhwar, 2006). The fact is that human is the indispensable source of competitive edge and organizations can efficiently and effectively achieve its objectives over the best utilization of the available human resources (Tan \& Nasurdin, 2011). It is thus an accredited fact that the organizational efficiency and effectiveness solely reliant upon effective and strategic policies of recruitment and selection in organizations. This, in turn, will improve the working efficiency and effectiveness and pays way towards the overall organizational performance (Ali et al., 2015). In this regard, the selection process requires the attention of the top management of the organization to induce capable and committed workforces by applying the fair and merit-based policies in the organization, which in turn, will help organizations for attaining targets effectively and efficiently (Malam et al., 2016).

\section{Training and Development}

The training and development are also considered as a vital component of HRM practices. In this regard, when the selection process is accomplished, then organizations are required to arrange an orientation program to introduce the new inductees with existing workforces (Tan \& Nasurdin, 2011). The main purpose of training is to nurture and update the abilities and competencies of employees aligned with the organizational objectives. The concept of training and development comprises two ideas like training and development (Rahman, Sambasivan \& Wong, 2013). In this regard, training is the process by which individuals are taught critical skills and knowledge while development tends to prepare individuals for additional responsibilities which help them to develop their existing skills and knowledge (Aragon, Jimenez \& Valle, 2014). Related literature revealed that training and development have an inspiring link with organizational performance and have a notable effect on organizational performance. The training and development is a continuous process that needs to be arranged regularly, which will help the organizations to achieve strategic objectives (Malam et al., 2016).

\section{Organizational Performance}

The organizational performance is mainly the amalgamation of different attributes which, when combined, lead to organizational performance. Every organization desires to achieve its predefined objectives while predominantly emphasizing its ability to constantly preserving its survival and profitability in which the efficiency and effectiveness count extremely (Matthew, 2004). In addition to 
efficiency and effectiveness, human resource management practices also count for organizational performance and success. In this regard, the organizational efficiency denotes the ability of organizations to minutely plan all the dimensions of available resources concerning their accessibility and usage (Alinaitwe, Mwakali \& Hansson, 2009). The literature revealed that effectiveness concerning the different organizational practices is a source of organizational success. The success is considered a vital factor in making decisions in the organization (Kumar \& Gulati, 2010). The effectiveness denotes to achieve desired results and for this purpose, the organizations are required to design long-term strategic planning based on the requirements of the organizations (Haq et al., 2018).

\section{Organizational Trust (Mediator)}

The organizational trust is used in the current study as a mediator in connection amid HRM practices and organizational performance. The related literature revealed that organizational trust is a critical component in the relationship between both concepts. Concerning relationships, in organizations, trust is a prominent concern about collegial relationships, employee-supervisor relationships, and supervisor-management relations (Hassan, Toylan, Semerciöz \& Aksel, 2012). The literature reveals that trust is playing a facilitating role when human resource management practices are alive and when organizations are efficient and effective about their available resources (Pervaiz, Imran, Mobeen \& Khan, 2014). Here exist two perceptions about trust, in this regard, one relates to the outcomes regarding the individual and organization viewpoint while the second denotes to strengthen/weakened relationship between the two concepts (Lazim \& Perlis, 2016). Similarly, trust act as a facilitator in the relation between the variables (predictors and criterion). Trust always helps organizations concerning positive outcomes regarding organizational activities. In this regard, trust is the most significant predictor of organizational performance (Judeh, 2016).

\section{Figure 1 Conceptual Framework}

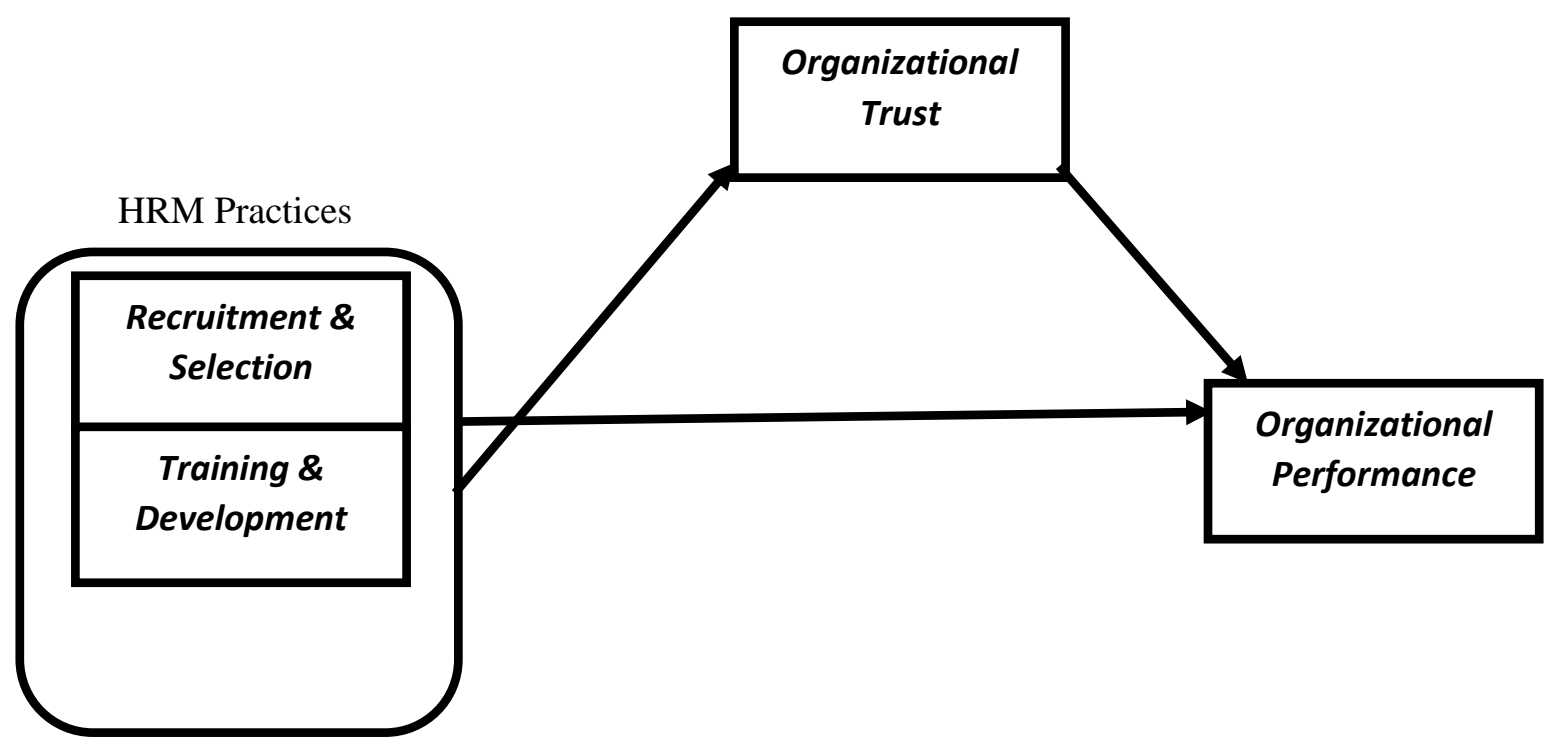

\section{Research Hypotheses}

$\mathbf{H}_{1}$ : $\quad$ There is a significant association between independent, dependent and mediator (correlation).

$\mathbf{H}_{2}$ : Organizational trust strengthens the relationship between HRM practices \& organizational performance (multiple regression).

$\mathbf{H}_{3}$ : Group means differences in respondents' opinions regarding experience towards the research variables (t-test).

$\mathbf{H}_{4}$ : Group means differences in respondents' opinions regarding gender towards the research variables (t-test).

\section{Research Methodology}

\section{Research Philosophy \& Approach}

The epistemological philosophy presents two options like positivism and phenomenology. The positivist approach is related to the work with visible and noticeable social truth and feelings of such research can be generalized and further which identifies the tangible facts and observable events. The 
phenomenological approach is to determine the reality behind the situation (Nicholas \& James, 2008). As compared to positivism, phenomenology is very complicated, thus, positivism is the research philosophy of the current study. Similarly, in social sciences, different approaches are used by researchers for a particular purpose. The researcher adopted a survey approach (Sekaran \& Bougie, 2013) for conducting the present study. The reason behind this is that the survey is one of the most crucial tools for measuring the attitude of a large population. In the survey, there are diverse tools used for collecting first-hand data or collecting data from a primary source like an interview, observation, and the questionnaire (Donald \& White, 2009). In this regard, the researcher used a wellstructured questionnaire as a data collecting instrument from respondents in the present study.

\section{Methods \& Procedures}

All faculty members working in the southern region of Khyber Pakhtunkhwa holding different positions is the target population of the study. There are 1947 faculty members in Public sector universities while 1165 faculty working in Private sector universities in Khyber Pakhtunkhwa (Statistical Data HEC, 2015-2016). Through stratified random technique, a sample of 354 teachers who are working in different private and public sector universities in KP was selected by using the Yamane (1967) simplified formula. For measuring present study variables, an adapted version of the questionnaire was used for collecting data from the respondents of the study. Measures were extracted from the previous studies and already used by many researchers in their studies. For data analysis, various statistical tools like scale reliability, correlation, simple regression, and multiple regression are employed.

\section{Validity and Reliability}

Assessing the scale validity content is an early critical phase in improving instrument validity in the social research process (Haynes, Kubany \& Richard, 1995). Through the experts' opinions, hailing from social sciences, the instrument was certified after the pilot study. The experts suggested some changes in the contents of the instrument which was later on corrected by the researcher while finalizing the instrument. For construct validity, exploratory factor analysis was used and sample adequacy case Bartlett Test of Sphericity and Kaiser-Meyer-Olkin Tests were used.

\begin{tabular}{clll}
\hline \multicolumn{3}{c}{ Reliability Statistics } & \\
\hline S. No & Constructs & Items & $\alpha$ \\
1 & HRM Practices & 9 & .779 \\
2 & Organizational Performance & 6 & .790 \\
3 & Organizational Trust & 7 & .792 \\
4 & Questionnaire & 22 & .907 \\
\hline
\end{tabular}

\begin{tabular}{lllll}
\hline \multicolumn{4}{c}{ Validity Statistics on HRM Practices } & \\
\hline KMO measure of sampling adequacy & & .774 & Matrix & \\
& Appr. Chi-Squa & 866.698 & Items & Factor Loading \\
Bartlett's test of Sphercity & df & 21 & HRM P1 & .844 \\
& Sig & 0.000 & HRM P 3 & .454 \\
& Required & Computed & HRM P 4 & .523 \\
KMO test & $=$ or $>=.7$ & .774 & HRM P 5 & .485 \\
Bartlett's test & $=$ or $<.05$ & .000 & HRM P 6 & .465 \\
Factor Loading & $=$ or $>.4$ & & HRM P 7 & .835 \\
& & & HRM P 8 & .846 \\
\hline
\end{tabular}

\begin{tabular}{lllll}
\hline \multicolumn{5}{c}{ Validity Statistics on Organizational Performance } \\
\hline KMO measure of sampling adequacy & & .784 & Matrix & \\
& Appr. Chi-Squa & 708.544 & Items & Factor Loading \\
Bartlett's test of Sphercity & df & 15 & OP1 & .688 \\
& Sig & 0.000 & OP2 & .742 \\
& Required & Computed & OP3 & .676 \\
KMO test & $=$ or $>=.7$ & .784 & OP4 & .795 \\
Bartlett's test & $=$ or $<.05$ & .000 & OP5 & .502 \\
Factor Loading & $=$ or $>.4$ & & OP6 & .878 \\
\hline
\end{tabular}




\begin{tabular}{lllll}
\hline \multicolumn{4}{c}{ Validity Statistics on Organizational Trust } \\
\hline KMO measure of sampling adequacy & & .801 & Matrix & \\
& Appr. Chi-Squa & 629.299 & Items & Factor Loading \\
Bartlett's test of Sphercity & df & 15 & Trust1 & .767 \\
& Sig & 0.000 & Trust2 & .781 \\
& Required & Computed & Trust3 & .638 \\
KMO test & $=$ or $>=.7$ & .801 & Trust & .775 \\
Bartlett's test & $=$ or $<.05$ & .000 & Trust5 & .465 \\
Factor Loading & $=$ or $>.4$ & & Trust7 & .829 \\
\hline
\end{tabular}

\section{Empirical Findings}

\section{A. Correlation (Associations)}

$\mathbf{H}_{\mathbf{1}}$ : There is a significant association between independent, dependent and mediator (correlation).

\begin{tabular}{|c|c|c|c|c|}
\hline Construct & & HRM Practices & OT & $\mathrm{OP}$ \\
\hline \multirow[t]{2}{*}{ HRM Practices } & Pearson Correlation & 1 & & \\
\hline & Sig. (2-tailed) & - & & \\
\hline \multirow{2}{*}{ Organizational Trust (OT) } & Pearson Correlation & $.735 * *$ & 1 & \\
\hline & Sig. (2-tailed) & .000 & - & \\
\hline \multirow{2}{*}{$\begin{array}{l}\text { Organizational Performance } \\
\text { (OP) }\end{array}$} & Pearson Correlation & $.601 * *$ & $.772 * *$ & 1 \\
\hline & Sig. (2-tailed) & .000 & .000 & - \\
\hline
\end{tabular}

In the above table, correlation coefficients of the predictor with mediator and criterion variables show the positive and significant association. Results revealed that independent variable i.e. HRM practices are significantly positively associated with mediator i.e. organizational trust and dependent variable i.e. organizational performance. Results show a positive and significant association of organizational performance with HRM practices $(\mathrm{R}=.601 \& \mathrm{P}=.000)$ and the organizational trust $(\mathrm{R}=.772 \& \mathrm{P}=$ $.000)$. Similarly, there is significant and positive association between the HRM practices and organizational trust $(\mathrm{R}=.735 \& \mathrm{P}=.000)$. On the bases of the above findings hypothesis, one $(\mathrm{H} 1)$ is accepted.

\section{B. Mediation Analysis}

$\mathbf{H}_{2}$ : Organizational trust strengthens the relationship between HRM practices \& organizational performance (multiple regression).

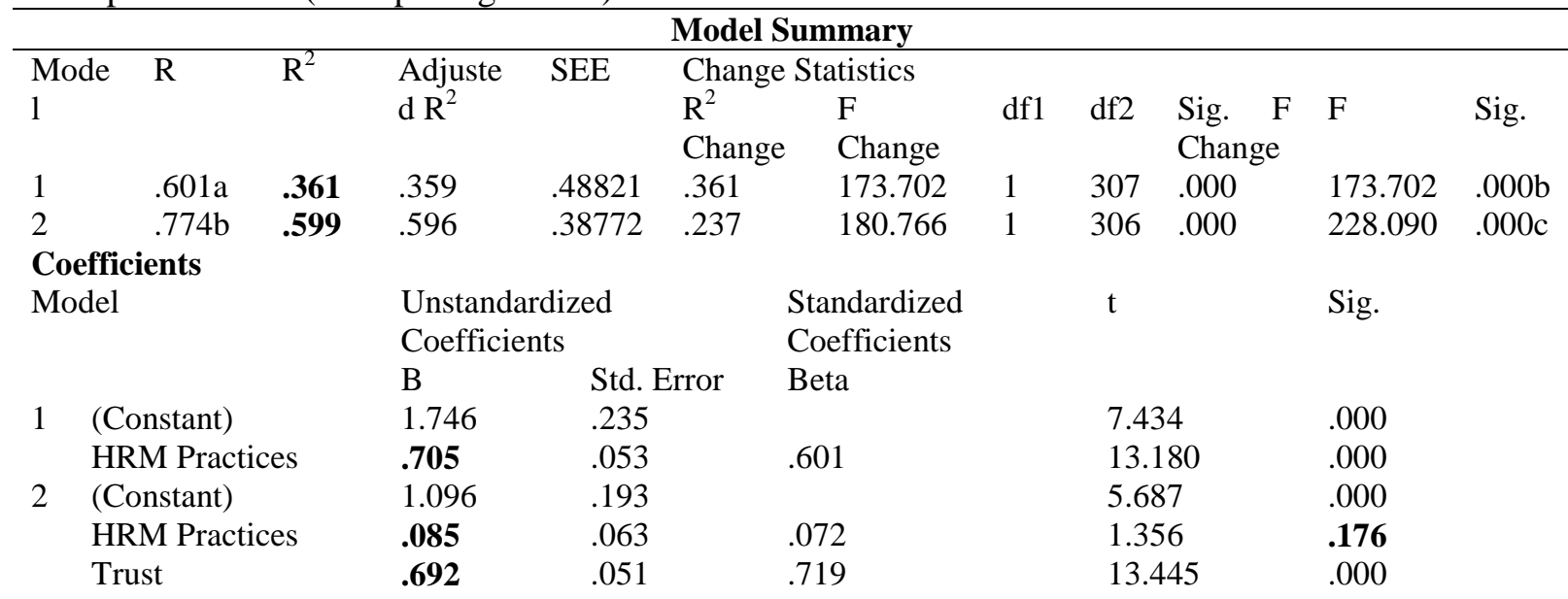

a. Predictors: HRM Practices b. Mediator: Organizational Trust c. Dependent: Organizational Performance

Organizational trust is used as the mediator in the relationship between HRM practices and organizational performance. For confirming the mediating role of organizational trust in the association of HRM practices and organizational performance, multiple regression analysis is adopted. The multiple regression provides two model models. In the first model, the $\mathrm{R}^{2}$ is $36 \%$, which has been increased to $60 \%$ after the addition of organizational trust as a mediator. The results further show that in the first model, the Beta value of HRM practices (.705) has been reduced to (.085) when the organizational trust is used as a mediator. Therefore, the increase in $\mathrm{R}^{2}$ (from $36 \%$ to $60 \%$ ) and the decrease in Beta values (from .705 to .085) confirms that organizational trust is playing the role of mediator in the relationship between HRM practices and organizational performance. Therefore, hypothesis No. 2 is accepted. 


\section{Group-Mean Differences}

$\mathbf{H}_{3}$ : Group means differences in respondents' opinions regarding experience towards the research variables (t-test).

\begin{tabular}{|c|c|c|c|c|c|c|c|c|}
\hline \multicolumn{9}{|c|}{ Group Statistics (Experience) } \\
\hline \multirow{3}{*}{\multicolumn{2}{|c|}{ HRM Practices }} & Level & $\mathrm{N}$ & Mean & & Std. Deviation & \multicolumn{2}{|c|}{ Std. Error Mean } \\
\hline & & Senior & 145 & 4.2851 & & .52277 & \multicolumn{2}{|c|}{.04341} \\
\hline & & Junior & 164 & 4.4268 & & .50998 & \multicolumn{2}{|l|}{.03982} \\
\hline \multicolumn{2}{|l|}{ Organizational } & Senior & 145 & 4.7319 & & .64940 & \multicolumn{2}{|l|}{.05393} \\
\hline \multicolumn{2}{|l|}{ Performance } & Junior & 164 & 4.8985 & & .56325 & \multicolumn{2}{|l|}{.04398} \\
\hline \multirow{2}{*}{\multicolumn{2}{|c|}{ Organizational Trust }} & Senior & 145 & 4.6709 & & .65645 & \multicolumn{2}{|l|}{.05452} \\
\hline & & Junior & 164 & 4.9965 & & .57164 & .04464 & \\
\hline \multicolumn{9}{|c|}{ Independent Samples Test } \\
\hline & & & & $\mathrm{F}$ & Sig. & $\mathrm{t}$ & df & $\begin{array}{l}\text { Sig. (2- } \\
\text { tailed) }\end{array}$ \\
\hline \multirow[t]{2}{*}{ HRM Practices } & \multirow{2}{*}{\multicolumn{3}{|c|}{$\begin{array}{l}\text { Equal variances assumed } \\
\text { Equal variances not assumed }\end{array}$}} & .010 & .921 & -2.410 & 307 & .017 \\
\hline & & & & & & -2.407 & 300.395 & .017 \\
\hline \multirow{4}{*}{$\begin{array}{l}\text { Organizational } \\
\text { performance } \\
\text { Organizational } \\
\text { Trust }\end{array}$} & \multirow{2}{*}{\multicolumn{3}{|c|}{$\begin{array}{l}\text { Equal variances assumed } \\
\text { Equal variances not assumed }\end{array}$}} & 2.615 & .107 & -2.415 & 307 & .016 \\
\hline & & & & & & -2.394 & 287.065 & .017 \\
\hline & \multirow{2}{*}{\multicolumn{3}{|c|}{$\begin{array}{l}\text { Equal variances assumed } \\
\text { Equal variances not assumed }\end{array}$}} & .793 & .374 & -4.660 & 307 & .000 \\
\hline & & & & & & -4.621 & 287.606 & .000 \\
\hline
\end{tabular}

For checking group means differences in opinion regarding experience related to present study variables, t-test was applied. Experience has widely used as a demographic variable in connection to the research variables likewise, HRM practices (.017), organizational performance (.016), and organizational trust (.000). The results showed that experience has shown significant group means differences regarding all research variables, but its impact is higher on organizational trust as compared to other research variables. Therefore, hypothesis No. 3 is accepted.

$\mathrm{H}_{4}$ : Group means differences in respondents' opinions regarding gender-related to present study variables.

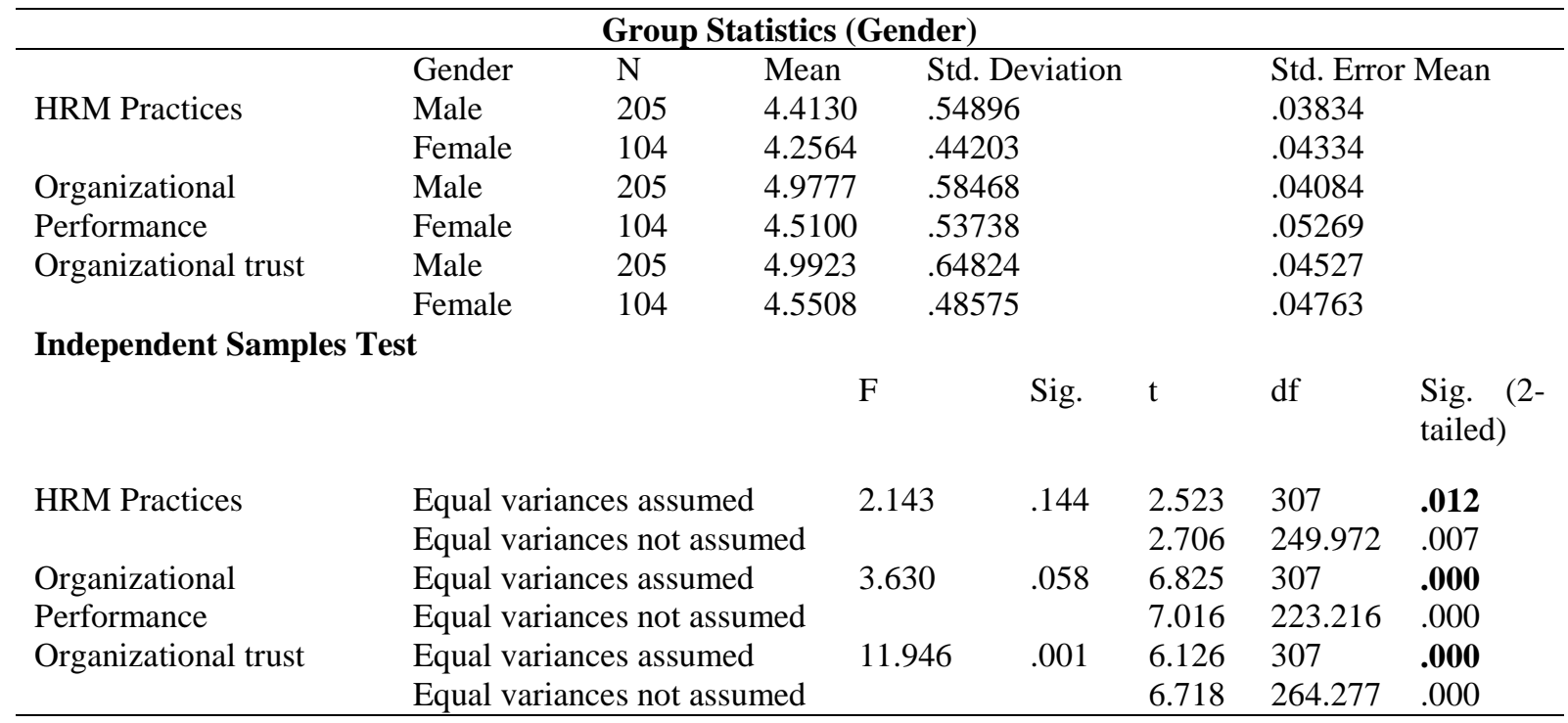

The t-test was used to examine the group mean differences regarding gender respecting the present study variables. Results show that all the research variables have shown significant group means difference concerning all research variables likewise, HRM practice (.012), organizational performance (.000), and organizational trust (.000). Findings of the above analysis support hypothesis four (H4), hence $\mathrm{H} 4$ is also accepted.

\section{Discussions and Conclusion}

The human resources are widely recognized as the competitive source for the sustainable edge of organizations. The management of human resources becomes a challenging task for an organization to survive in an existing competitive environment (Becker, Huselid \& Ulrich, 2001). Consequently, numerous studies defined HRM practices as the set of formal policies and practices utilized by organizations to manage their human resources by emerging their abilities to chase the predefined 
objectives (Stavrou, Charalambous \& Spiliotis, 2007). This can be possible when organizations can effectively plan and implement HRM practices effectively. Thus, the organizations are required to select the best human capital for the organizations (recruitment and selection) (Tan \& Nasurdin, 2011), develop and nurture knowledge, skills, capabilities, and interpersonal relations (training \& development) (Rahman, Sambasivan \& Wong, 2013).

Keeping in view the results from the previous studies and the results obtained through statistical procedures in the present study, it has been concluded that HRM practice (recruitment \& selection and training \& development) has a positive and significant association and impact on organizational performance. Similarly, organizational trust is also validated as a significant mediator in the relationship between HRM practices and organizational performance. Likewise, the demographic variables (experience \& gender) have also shown the significant group means differences regarding the research variables. On the part of institutional management, their responsibilities are not only limited to recruit and select suitable candidates for employment rather it is also the responsibility of the management to ensure the proper training and development programs to update knowledge and skills of the workforce. Therefore, results from the testing of the hypothesis validated the significant relationships among the research variables under consideration in the present research work.

\section{References}

Ali, E., Saeed, T., Soomro, A., \& Aslam, M. (2015). Human resource information system: role in hrm practices and organizational performance. Cambridge Business \& Economics Conference. ISBN: 9780974211428.

Alinaitwe, H., Mwakali, J. A., \& Hansson, B. (2009). Organizational effectiveness of Ugandan building firms. Journal of Civil Engineering and Management, 15(3), 281-288.

Amin, M., Ismail, W., Rasid, S., \& Selemani, R. (2014). The Impact of Human Resource Management Practices on Performance. The TQM Journal, 26(2), 125-142.

Aragon, M., Jimenez, D. J., Valle, R. S. (2014). Training and performance: The mediating role of organizational learning. BRQ Business Research Quarterly, 17(3): 161-173.

Arshad, A., Azhar, S. M., Khawaja, K. J. (2014). Dynamics of HRM Practices and Organizational Performance: Quest for Strategic Effectiveness in Pakistani Organizations. International Journal of Business and Social Science, 5(9).

Awais, M., Afzal, M., Shahzadi, I., \& Khalid, U. (2017). The Impact of Human Resource Management Practices on Organizational Performance. International Journal of Engineering and Information Systems, 9 (1), 165-178.

Becker, B. E, Huselid, M. A, \& Ulrich D. (2001). HR Scorecard: Linking people, strategy and performance. Harvard Business School Press: Boston, MA.

Colakoglu, S., Lepak, D., \& Hong, Y. (2006). Measuring HRM Effectiveness: Considering Multiple Stakeholders in a Global Context. Human Resource Management Review, 16, 209-218.

Donald, H. M., \& White, T. L. (2009). Research Methods. Cengage Learning. ISBN 0-495 60219-1.

Gordon, G., \& Whitchurch, C. (2007). Managing human resources in higher education: The implications of a diversifying workforce. Higher Education Management and Policy, 19(2), 131-153.

Haq, A. M., Ilyas, M., \& Mahmood, K. (2018). Human Resource Practices and Organizational Performance in Pakistan. Pakistan Business Review, 20 (1), 137-148.

Hassan, M., Toylan, N. V., Semerciöz, F., \& Aksel, I. (2012). Interpersonal trust and its role in organizations. International Business Research, 5(8), 33-39.

Hayes, A. F., \& Agler, R. A. (2014). On the standard error of the difference between independent regression coefficients in moderation analysis. Multiple Linear Regression Viewpoints, 40 (2), 16-27.

Judeh, M. (2016). The influence of organizational trust on job performance: Mediating role of employee engagement. International Journal of Business Research, 16 (5), 53-66.

Katou, A., \& Budhwar, P. (2006). The Effect of Human Resource Management Systems on Organizational Performance: Test of a Mediating Model. International Journal of Human Resource Management, 17(7), 1223-1253. 
Kumar S., \& Gulati R., (2010). Measuring efficiency, effectiveness and performance of public sector organizations. International Journal of Productivity and Performance Management. 59 (1), $51-74$.

Malam, S., Tang, M., Raihan, J. (2016). An empirical analysis of HRM practices and organizational performance relationship in the context of developing nation: the moderating effect of ethical climates. International Journal of Management Research \& Review, 6 (10), 1463-1481.

Matthew, K. G. (2004). A DEA approach for evaluating the efficiency and effectiveness of urban transit systems. European Journal of Operational Research. 152 (2), 354-364.

Moideenkutty, U., Lamki, A., \& Murthy, Y. R. (2012). HRM practices and organizational performance in Oman. Personnel Review, 40(2), 239-251.

Nicholas, B., \& James, E. (2008). The Blackwell Companion to Philosophy. John Wiley \& Sons. ISBN 978-0-470-99787-1.

Paauwe, J., \& Boselie, P. (2003). Challenging 'strategic HRM' and the relevance of the institutional setting. Human Resource Management Journal, 13(3), 56-70.

Pervaiz, U., Imran, M., Arshad, Q., Haq, R., Mobeen, M., \& Khan, K. (2014). Human resource practices and knowledge sharing: The moderating role of trust. International Journal of Organizational Leadership, 5(2016) 15-23.

Popescu, M., \& Băltăreţu, A. (2012). Considerations regarding the role of human resources in Romanian educational process revealed by national education law. Procedia-Social and Behavioral Sciences, 46, 3993-3998.

Rahman, A., Sambasivan, M., \& Wong, F. (2013). Training \& organizational effectiveness: moderating role of knowledge management process. European Journal of Training and Development, 37(5), 472-488.

Sekaran, U., \& Bougie, R. (2013). Research Methods for Business: A Skill-Building Approach (6th Ed.). John Wiley and Sons, Inc.

Stavrou, E. T., Charalambous, C., \& Spiliotis, S. (2007). Human resource management and performance: A neutral network analysis. European Journal of Operational Research, 181, 453-467.

Tan, C., \& Nasurdin, A. (2011). Human Resource Management Practices and Organizational Innovation: Assessing the Mediating Role of Knowledge Management Effectiveness. The Electronic Journal of Knowledge Management, 9(2), 155-167.

Wang, D. S., \& Shyu, C. L. (2008). Will the strategic fit between business and HRM strategy influence HRM effectiveness and organizational performance? International Journal of Manpower, 29 (2), 92-110. 